„Bohemistyka” 2020, nr 4, ISSN 1642-9893

Joanna KORBUT

DOI: $10.14746 /$ bo. 2020.4 .6

Uniwersytet Jagielloński

\section{Konwencja czy kreacja? Rzecz o Češtinie 2.0}

Keywords: conventional, creative, connotation, neologism, (not) acceptable.

Słowa klucze: konwencjonalny, kreatywny, neologizm, neosemantyzm, motywacja

\section{Abstract}

New words are a natural phenomenon in every language, it's inevitable effect of cultural and social changings of modern community. In this article author explores lexical material collected and presented in Čeština 2.0, unusually crowd-sourced lexical material collected and presented in Ceština 2.0, unusually crowd-sourced
online dictionary. Special attention is given to the semantic structure and motivation of gathered words. Research show that in analyzed material we can find both, convention and creativity in making new words (at the orthographic, morphological and semantic level). The main question is, how persistent new words are, how many of them will be used by the people in everyday communication.

Tworzenie nowych wyrazów będacych odbiciem zmieniającej się rzeczywistości to naturalny proces w każdym języku. Sposoby uzupełniana słownictwa sa różne, i jak pokazała analiza badanego materiału, internauci wykorzystują je na różne sposoby. Čeština 2.0 i jej twórcy pokazują jak bawić się językiem, jak wykorzystywać znane (konwencjonalne) schematy słowotwórcze w niebanalny, kreatywny sposób. W ocenie zaprezentowanego materiału pod uwage wzięto zarówno mechanizmy tworzenia wybranych jednostek leksykalnych, jak również zrozumiałość wynikająca $\mathrm{z}$ właściwej motywacji, otwartym pozostawiając pytanie, które z nich zyskają szerszy zasięg i na stałe wejdą do zasobu słownego współczesnego języka czeskiego.

Kreatywność jest podobno jedną z najbardziej typowych ludzkich cech, dzięki której tworzone są wartościowe koncepcje, pomysły, rozwiązania. Fascynujące jest nie tylko to, co powstaje w wyniku takiego procesu, ale także to, w jaki sposób powstaje i jakie czynniki, motywacje się za tym kryją. Co powoduje, że ludzie są zdolni do tworzenia nowych rzeczy, co i dlaczego jest twórcze, a co nie? Czy kreatywność to wyzwanie i konieczność? Zapewne z niektórymi z tych pytań musieli się zmierzyć twórcy projektu Čeština 2.0.
Jak podkreślają inicjatorzy projektu Čeština 2.0, jest to tworzony przez szeroką społeczność internetową słownik internetowy, który powstał w roku 2009 i który ,ukazuje, že čeština má šmrnc, vtip i budoucnost. Zahrnuje zbrusu nová slova, ale i slangové, regionální či jinak zajímavé výrazy ze všech zákoutí mateřštiny. Češtinu 2.0 vytváříme my všichni každý den" (https://cestina20.cz/o-cestine-2-0). Jego twórcą czy raczej pomysłodawcą jest Martin Kavka, „łowca słów”, którego zamiarem było stworzenie czeskiego Urban Dictionary ${ }^{1}$. Po blisko dziesięciu latach od stworzenia strony internetowej zaprezentowany materiał doczekał się wydania książkowego i nakładem Jan Melvil Publishing ukazała się Hacknutá čeština - neortodoxní slovník dnešní mateřstiny ${ }^{2}$.

Ten nietypowy zbiór leksykograficzny liczy ponad 16 tysięcy haseł $^{3}$ i jest codziennie poszerzany o nowe jednostki. Hasło słownikowe ma dość prostą i typową dla tego rodzaju publikacji budowę. Pojawia się tu bowiem definicja znaczenia, niekiedy też przykład użycia ${ }^{4}$, autor (jego imię/nazwisko/nick) oraz data umieszczenia hasła na stronie internetowej.

Čeština 2.0 jest tworzona przez internautów, każdy może w tym tworzeniu wziąć aktywny udział, umieszczając nowe słowo na wyżej wymienionej stronie. Mogą to być wyrazy tylko gdzieś zasłyszane, ta-

JJsem Martin Kavka a Češtinu 2.0 jsem založil jako „,český Urban Dictionary“ v lednu 2009. Samotný nápad je ještě o rok starší. Všechno začalo v tramvaji, kde ke mně z rozhovoru dvou slečen doputovalo první slovo sračkogán. Když jsem jich měl v notesu pár desítek, vznikl web" (https://cestina20.cz/o-cestine-2-0).

${ }^{2}$ Kavka, Škrabal a kol. 2018. Online: https://www.melvil.cz/kniha-hacknuta-cestina. Od marca 2019 roku w internetowej telewizji Seznam można oglądać program telewizyjny pod tym samym tytułem.

${ }^{3}$ Stan na dzień 3.01.2020-16291 słów.

${ }^{4}$ Niestety, nie pojawia się informacja o źródle podanego cytatu, czy jest on zaczerpnięty z mediów, z literatury, z tzw. języka mówionego, czy może po prostu wymyślony przez autora hasła na potrzeby tego słownika. To znacznie utrudnia analizę i powoduje, że prezentowane przykłady użycia nie są w pełni wiarygodnym materiałem badawczym. 
kie, których jest się autorem lub „tylko" użytkownikiem ${ }^{5}$. Jak czytamy, ,slýcháme je kolem sebe - poletují v tramvajích a hospodách, smějí se jim kolegové, sociální sítě je milují a některá to dotáhla až do médií" (https://www.melvil.cz/kniha-hacknuta-cestina). W tym specyficznym słowniku znajdziemy zarówno wyrazy dotyczące szeroko pojętego życia codziennego (we wszystkich jego aspektach), jak i polityki, kultury, ale ,at' už se týkají alkoholu, politiky, sexu či jakékoli jiné stránky života, všechna je spojuje láska $\mathrm{k}$ češtině a radost $\mathrm{z}$ její hravosti" (https://www.melvil.cz/kniha-hacknuta-cestina). Znamienne są słowa umieszczone na stronie internetowej projektu, „Čeština 2.0 je slovník, který trolí češtináře už od roku 2009", , tym samym twórcy przyznają, że ich zamiarem jest zachęcanie, prowokowanie ludzi do uruchomienia wyobraźni językowej, do tworzenia rzeczy, słów nowych (w domyśle niebanalnych), do tworzenia, a nie tylko odtwarzania.

Na początek warto zastanowić się, czym różni się bycie kreatywnym od bycia konwencjonalnym. Słownik Języka Polskiego przedstawia takie oto wyjaśnienia: konwencjonalny: 1. 'zgodny z konwenansem', 2. 'postępujący zgodnie z konwenansem', 3. 'oparty na konwencji - przyjętym zwyczaju', 4. 'niewykraczajacy poza schematy, nieoryginalny', 5. 'znany od dawna, tradycyjny' (https://sjp.pwn.pl/szukaj/konwencjonalny.html). Znaczenie przymiotnika kreatywny wydaje się nieco bardziej tajemnicze. Ciekawą i wyczerpującą prezentację stanu badań nad tym zagadnieniem przedstawia w swojej pracy Łukasz Maźnica (2013), podkreślając, że trudno o jedną, ogólnie przyjętą definicję tego pojęcia, każda z nich podkreśla natomiast, że krea-

${ }^{5}$ Spora część z omawianych w niniejszej pracy wyrazów poświadczona jest w Slovníku nespisovné češtiny (2009), np. ajfelka, ajtảk, bonzaj, čekovat, čipák, květák, kuřbaba, nakupák, salamista. Przykłady użycia niektórych możemy znaleźć $\mathrm{w}$ Internecie, np. anděl (reklamowany jako nemocniční, pooperačni košile), Al Čapone, babišátko, cédéćka, hovnorár̆ lídlo, nakupák, přizdistáč, telebrita. Szeroko używane są też określenia Lex Babiš, Pitomio.

${ }^{6} \mathrm{Https}: / /$ cestina20.cz/o-cestine-2-0/; trolit 'provokovat někoho, často v diskuzích na internetu (ale nejen tam)' (zob. https://cestina20.cz/slovnik/trolit),_češtinár 'bohemista, nauczyciel języka czeskiego, jego znawca, słuchacz'. tywność opiera się na pomysłowości, a ta przejawiać się może w różnych dziedzinach życia.

[...] kreatywność to proces prowadzący do nowego wytworu, który jest akceptowalny i uznawany za użyteczny dla pewnej grupy w pewnym okresie [Stein 1953]. [...] W ciekawy sposób o kreatywności pisze Rosabeth Moss Kanter. Jej zdaniem, jest to specyficzny sposób myślenia, pozwalający „wstrząsać” posiadanymi informacjami układać je w nową całość, która łamie powszechnie przyjęte schematy [Kanter 2001, s. 261]. Jeszcze inne spojrzenie prezentuje Richard Florida. Utożsamia on kreatywność $\mathrm{z}$ umiejętnościa znajdowania nowych pomysłów. Jak pisze, jest ona wielowymiarowa, występuje w wielu wspierających się wzajemnie formach, może zostać wykorzystana do wielu różnych celów, a jej istnienie jest powszechne i ciągłe [Florida 2010, s. 9, 28, 335] (Maźnica 2013, s. 399-400).

W przywoływanych przez Maźnicę opisach powtarzają się pewne cechy: akceptowalny, użyteczny, nowy czy - jak podkreślają niektórzy - łamiący przyjęte schematy. Jeśli więc przyjmiemy, że - jak wynika z powyższego cytatu - kreatywny znaczy akceptowalny i użyteczny, to spora część analizowanych w artykule (a zawartych w Čeština 2.0) wyrazów i połączeń wyrazowych jednak taka nie jest. Niektóre z nich wyraźnie przekraczają granice tabu językowego i obyczajowego, dlatego przez wielu moga być uznane za nieakceptowalne, np. kuřbaba 'kobieta, która lubi sex oralny' ${ }^{7}$, čvančary 'bardzo duże piersi' (od nazwiska aktorki Jitki Čvančarovej), tekut'ák 'biegunka (dosł. wulg. sraczka)', pičimýdlo 'mydło do higieny intymnej dla kobiet' (czes. píča - pol wulg. 'cipa'), babiškunda 'była wysoko postawiona managerka holdingu, która obecnie kieruje ministerstwem, województwem, miastem' (kontaminacja nazwiska Babiš i rzeczownika kunda - pol. wulg. 'cipa', też pogardliwie o kobiecie), czy sračkogán 1. 'seria kilku porażek, kłopotów w krótkim czasie', 2. 'bardzo wulgarny człowiek' (por. pol.język jak kloaka); 3. 'kanalizacja, toale-

\footnotetext{
${ }^{7}$ Definicje znaczeń jednostek leksykalnych omawianych w niniejszej pracy opracowano na podstawie czeskich opisów zawartych na stronie https://cestina20.cz. Same definicje tworzone sa przez internautów w dość specyficzny sposób, opis znaczenia i język, którym posługuja się autorzy sa dość niebanalne i czasami mocno kontrowersyjne pod względem zarówno formy, jak i treści.
} 
ta, odpady'. Jak widać, mamy tu do czynienia z naruszeniem etyki i estetyki słowa. Grzeczność językowa to istotny składnik komunikacji i chociaż granice tolerancji oraz stopień wrażliwości na określone zachowania językowe mogą być u różnych ludzi różne, to - jak podkreśla Małgorzata Marcjanik (2007, s. 12) - pewnych zachowań zaniechać nie wypada, a ktoś, kto mówi do nas i używa wulgaryzmów, nie tylko mówi nieestetycznie, ale nas nie szanuje.

Na ten aspekt komunikacji zwrócił uwagę już Zenon Klemensiewicz (1965, s. 1-8), który pisząc o higienie językowej, wymienia m.in. takie przykłady jej łamania, jak używanie wyrazów wulgarnych, obraźliwych, sprośnych. Przytoczone czeskie przykłady wydają się tę higiene wyraźnie naruszać. Zwraca na to uwage także Monika Zavřelová (2018), która w jednym ze swoich artykułów słusznie zauważa, że chociaż zadbano o formalną stronę publikacji (jako pozycji leksykograficznej) to „možná by však stálo za to přizvat i jakousi jazykovou policii. Některé výrazy jsou totiž daleko za hranicí vkusu, papír jim nesluší a pozná to i člověk lingvistikou nepolíbený" (Zavřelová 2018). Nie sposób nie zgodzić się z autorką, że niektóre propozycje zamieszczone w słowniku wzbudzają raczej litość niż zachwyt, a puryści językowi z pewnością nie powinni na tę stronę zaglądać.

W przytoczonych definicjach pojęcia kreatywność pojawia się również cecha 'bycia użytecznym'. O użyteczności niektórych analizowanych neologizmów trudno dyskutować. Czy bowiem naprawdę czeszczyzna potrzebuje takich słów, jak np. pichnik 'piknik zakończony seksem', hovnorár 'niewystarczające wynagrodzenie za wykonaną pracę' (czes. hovno 'gówno'), bakteriér 'pies zakażony chorobą bakteryjna', ronaldit 'symulować, udawać; od nazwiska piłkarza Cristiano Ronaldo', monstruace 'menstruacja, która ma bardzo gwałtowny i intensywny przebieg', crocsana 'kobieta lubiaca chodzić w wygodnym obuwiu plażowym' (Crocs - marka obuwia) ${ }^{, 8}$ ? A może to tylko element gry językowej, efekt dążenia internautów do humoru języko-

${ }^{8}$ W korpusie tekstowym https://www.korpus.cz nie znaleziono żadnych z wymienianych $\mathrm{w}$ tym fragmencie przykładów. Nieliczne przykłady użycia można znaleźć w Internecie, por. przypis 5. wego, w wyniku którego powstają neologizmy okazjonalne, które nie roszczą sobie żadnego prawa do leksykalizacji?

Bez względu jednak na kwestie użyteczności czy nieużyteczności nie sposób odmówić internautom pomysłowości (nowatorstwa?) w tworzeniu nowych wyrazów. Niektóre słowa są przejawem ich wyjątkowej kreatywności, są pomysłowe, choć czasem w dość specyficzny sposób. Do prawidłowej ich interpretacji często niezbędna jest znajomość tzw. kontekstu (zwłaszcza w przypadku neologizmów inspirowanych światem polityki - o czym mowa w dalszej części artykułu) czy znajomość języka angielskiego (w przypadku zapożyczeń). Jak widać, fantazja słowotwórczo-leksykalna powinna mieć pewne granice, ponieważ ,podstawowym warunkiem, który stawia się jednostce słowotwórczej, jest jej zrozumiałość wynikająca z właściwej motywacji" (Buttler i in. 1976, s. 94). Analizowane przykłady nie zawsze ten warunek spełniają, zdarzają się formacje nie tyle nieudane, co niezrozumiałe na pierwszy rzut oka. Ich motywacja wydaje się dość niezwykła, a relacja semantyczna między wyrazem podstawowym a pochodnym czasem nieczytelna. Magdalena Pastuchowa (2008, s. 19) nazywa takie derywaty ,pogmatwanymi” i stwierdza, że aby je zrozumieć i opisać, trzeba odwołać się do narzędzi leksykologicznych. Doskonałym przykładem wydaje się być přizdistáč. Stosunkowo łatwo wyodrębnimy w nim morfemy rdzenne: rzeczownik zed' 'ściana' i czasownik stát 'stać' oraz afiksy: při- i -áč, mimo to nie potrafimy od razu odpowiedzieć, co wyraz ten oznacza. Dlatego prawdopodobnie zdziwi nas, że jest to 'choinka tak brzydka, że trzeba ją postawić przy ścianie, żeby nie było widać jej brzydkiej strony’.

Spośród najbardziej kreatywnych przykładów umieszczonych na stronach Čeština 2.0 wymienić należy następujące: afronaut 1. 'emigrant z Afryki, podróżujący do nieznanej dla niego krainy, jaką jest Europa', 2. 'człowiek z fryzurą afro, w której twarz wygląda jak w hełmie lub kasku', akord ' 'wielkość biustu ,akurat (w sam raz) do

${ }^{9}$ Czes. akord 'współbrzmienie co najmniej trzech różnych dźwięków; system płacy, w którym wysokość wynagrodzenia zależy od ilości wyprodukowanego towaru lub od wykonanej normy' - pol. akord. 
ręki', Al Čapone ${ }^{10}$ 'premier Czech Andrej Babiš', anděl 'szpitalna koszula z wiązaniem na plecach' (por. anděl 'anioł'), berlín 'poczekalnia u lekarza, pełna ludzi o kulach, o laskach' (por. berla 'kula, laska'.), bonzaj 'bardzo niski człowiek; kurdupel' (por. bonsaj 'zminiaturyzowane drzewko uprawiane w płaskich doniczkach; sztuka hodowli takich drzewek'), cédéčka 'piersi w rozmiarze miseczki C lub D' (por. cédéčko = kompaktni disk' CD, płyta CD, płyta kompaktowa'), cvrček 'czujnik parkowania z sygnałem akustycznym' (por. cvrčet 'ćwierkać', cvrček 'świerszcz, cykada'), květák 1. 'fryzura afro, przypominająca swoim wyglądem kalafior', 2. 'mózg' (por. květák 'kalafior'), pikador'1 'hot dog', topinka 1. 'osoba, rzecz najlepsza ze wszystkich'; 2. członek, sympatyk partii politycznej TOP 09' (por. topinka 'grzanka, tost'). Podstawą motywacji analizowanych jednostek leksykalnych jest często metafora. Nowo tworzone wyrazy bowiem motywowane są podobieństwem cech zewnętrznych: wyglądu (afronaut - w znaczeniu 2.), anděl, květák, wielkości (bonzaj), oraz towarzyszącym czynności dźwiękiem (cvrček). Niekiedy wykorzystuje się skojarzenia między pojęciem zwerbalizowanym a nowo nominowanym pod względem posiadanej cechy immanentnej lub pełnionej funkcji, np. pikador, Al Čapone, czy grę słów, jak w przypadku rzeczowników berlín, czy topinka.

Iwona Kaproń-Charzyńska i Marek Wiśniewski w swoim artykule traktującym o kreatywności leksykalnej i etyce słowa podkreślają, że „Za pośrednictwem słownictwa utworzonego w wyniku niestandardowego łączenia środków językowych i/lub modyfikacji graficznych, stanowiących odstępstwo od obowiązującej konwencji zapisu wyrażeń, użytkownicy języka manifestują swoje postawy wobec świata. Są to przede wszystkim postawy negatywne związane $\mathrm{z}$ negatywnym wartościowaniem zjawisk rzeczywistości" (Kaproń-Charzyńska, Wi-

${ }^{10}$ Przydomek ten został nadany premierowi Babišovi po aferze Čapi hnizdo (pol. Gniazdo bociana, nazwa kompleksu wypoczynkowo-szkoleniowego, którego właścicielem jest A. Babiš), skandalu finansowym związanym z wyłudzeniem dotacji z UE.

11 Por. czes. pikador 'konny uczestnik corridy uzbrojony w pikę' - zob. http://prirucka.ujc.cas.cz/?slovo=pikador. śniewski 2018, s. 88-89). Nie sposób się z tymi słowami nie zgodzić, tym bardziej że znakomicie odnoszą się one również do sporej części analizowanego w niniejszej pracy materiału leksykalnego.

Doskonałym przykładem na owo pejoratywne wartościowanie sa $\mathrm{w}$ badanym materiale wyrazy związane $\mathrm{z}$ szeroko pojętą polityką czy raczej inspirowane polityka, politykami, związanymi z nimi wydarzeniami. Truizmem będzie stwierdzenie, że polityka odgrywa znaczącą rolę w życiu wszystkich ludzi, ale czescy politycy wydają się być nieustannym natchnieniem dla współtworzących omawiany słownik. Internauci nierzadko daja upust niechęci wobec poszczególnych osób, a prym wiedzie tu obecny premier Andrej Babiš. Neologizmów utworzonych bezpośrednio od jego nazwiska badź związanych $\mathrm{z}$ jego osobą jest nad wyraz dużo i są często używane, również w czeskich mediach (por. powszechne już Lex Babiš). Dotyczą one różnych sfer życia codziennego, nie tylko tego związanego z polityką. Oto niektóre z przykładów: Babišovy dobroty 'produkty koncernu Agrofert ${ }^{12}$, przeciętna cena, niska jakość', Babišova dálnice 'próba opisania rzeczywistości lepszej niż jest naprawdę"13 , babišárna 'wielkie oszustwo finansowe', babišmen 'niezłomny obrońca A. Babiša', babišit 'kłamać i wierzyć, że wszyscy dadzą się nabrać', babištan 'Czechy rządzone przez A. Babiša', babiština 'język czeski z dużymi „,naleciałościami” języka słowackiego', Lex Babišs' 'ustawa o konflikcie interesów'.

Nieco mniej ,,popularni” są wśród internautów inni politycy, np.:

- VÁCLAV KLAUS ${ }^{15}$ : klaus ‘jednostka zadufania i pychy’, klausoid, klausovec, klausovita, klausoláskař 'wielbiciel, zwolennik Václava Klausa', klausovka 1. 'zatwardziała zwolenniczka Václava Klau-

\footnotetext{
${ }^{12}$ Właścicielem Agrofertu jest A. Babiš.

${ }^{13}$ Por. frazeologizm Potěmkinovy vesnice - pol. wioski/wsie potiomkinowskie.

${ }^{14}$ Ustawa zakazuje przyszłym członkom rządu posiadania udziału w mediach, zakazuje również spółkom bẹdacym własnościa ministrów korzystania $\mathrm{z}$ funduszy publicznych. Premier Babiš jest właścicielem koncertu Agrofert, a za jego pośrednictwem dzienników Mladá Fronta Dnes, Lidové noviny i radia Impuls.

${ }^{15}$ W latach 1992-1998 premier rządu czeskiego, a w latach 2003-2013 prezydent Republiki Czeskiej.
} 
sa'; 2. 'tania parówka', Klaus-Klaus-Klan 'nowa partia polityczna V. Klausa i jego syna', klausoleum 'instytut, biblioteka byłego prezydenta V. Klausa, zajmujące się propagowaniem jego idei, poglądów, dokonań', klausule 'prezydenckie ułaskawienie' (por. czes. klauzule 'klauzula, warunek'), na klause 'o człowieku ubranym w bardzo ciasne spodnie' ${ }^{16}$, uklausit 'zabrać cudze pióro, długopis $^{17}$;

- MILOŠ ZEMAN ${ }^{18}$ : vinóza 'stan zamroczenia alkoholowego', zemáňa pejor.'niewykształcona kobieta pochodząca ze wsi, bezkrytycznie adorująca prezydenta Zemana', zemanbába 'zwolenniczka Milošô Zemana', zemandropitekus 'osoba z IQ dużo poniżej poziomu przeciętnego zwolennika M. Zemana',_zemandrtálec 'agresywny wyborca, zwolennik M. Zemana', zemanovská viróza/zemanóza 'kac', zemanslib 'obietnica, o której wiadomo, że nie zostanie spełniona', zemanýry 'sposób zachowania, zwyczaje, maniery M. Zemana';

- VÁCLAV HAVEL ${ }^{19}$ : Havlák' praskie lotnisko im. V. Havla', havlista 'fanatyczny zwolennik V. Havla', havlobot, havloid, havlojed pejor. 'zwolennik V. Havla', havlovka 'zatwardziała zwolenniczka V. Havla', havloween 'dzień rozpoczęcia tzw. aksamitnej rewolucji';

- TOMIO OKAMURA ${ }^{20}$ : blokamura 'blokowanie portali społecznościowych, stron internetowych przez grupę ludzi skupionych wokół T. Okamury', blokkake 'zbiorowa blokamura' (por. bukkake 'ro-

${ }^{16}$ Podczas przyjęcia na turnieju tenisowym w Pradze były prezydent był ubrany w takie właśnie ,przyciasne” spodnie.

${ }^{17} \mathrm{~W}$ czasie oficjalnej wizyty państwowej prezydenta Klausa w Chile prezydent przywłaszczył sobie pióro, którym podpisywane były dokumenty.

${ }^{18}$ Od marca 2013 roku do chwili obecnej prezydent Republiki Czeskiej, znany ze swojej słabości do alkoholu.

${ }^{19}$ Czeski dramaturg, pisarz, działacz antykomunistyczny. Ostatni prezydent Czechosłowacji (1989-1992) oraz pierwszy prezydent Czech (1993-2003).

${ }^{20}$ Czesko-japoński polityk, przedsiębiorca, działacz społeczny. dzaj grupowej praktyki seksualnej', z języka japońskiego), okamů$r a$ 'człowiek, który żyje w permanentnym strachu przed imigrantami i UE', Pitomio 'polityk T. Okamura' (por. pitomý 'głupi', pitomec 'głupek') ${ }^{21}$, pitomiovina 'głupota, bzdura';

- JIŘÍ DRAHOŠ ${ }^{22}$ : drahošit/drahoshit 1. 'głupota', 2. 'mówić głupoty', drahošovat 'wahać się, nie mieć odwagi', drahošovky 'okulary bez dioptrii (tzw. zerówki) noszone wyłącznie jako modny dodatek';

- MIROSLAV KALOUSEK ${ }^{23}$ : kalousek 'jednostka zła', kalouskovat 'odwracać od siebie uwagę poprzez wskazywanie na niepowodzenia innych osób’.

Jak widać, internauci wykazali się dużą pomysłowością i kreatywnością. Niektóre analizowane jednostki leksykalne są niewątpliwie godne uwagi, może nawet pochwały, niekiedy wywołują uśmiech na twarzy czytającego (np. Pitomio, Al Čapone). Zauważyć należy jednak, że większość wymienionych przykładów jest wyraźnie wartościująca. Jeśli internauci czerpią z polityki, to powstają na ogół wyrazy nacechowane wyraźnie pejoratywnie, pogardliwie. Sarkastyczne poczucie humoru internautów, tworzących takie neologizmy jak np. babiškunda, babiština, klausoleum, Klaus-Klaus-Klan, zemandertálec, czy drahoshit, świadczy o niezbyt pozytywnym, czasem wręcz obraźliwym stosunku do opisywanych polityków. W większości przezwisk zawarte są wyraźne aluzje do ich poglądów, określonych zachowań czy podejmowanych działań. Czasem do zrozumienia przezwiska potrzebny jest klucz, którym jest znajomość realiów życia poli-

${ }^{21}$ Przezwisko, wymyślone przez redakcję czasopisma Reflex, powstało prawdopodobnie w wyniki tzw. blendingu, czyli połączenia fragmentów dwóch słów (nazw własnych) Pinokio oraz Tomio.

${ }^{22}$ Wykładowca akademicki, w latach 2009-2017 prezes Akademii Nauk Republiki Czeskiej, kandydat na prezydenta, senator.

${ }^{23}$ Czeski polityk, poseł, były minister finansów Republiki Czeskiej. Z jego osobą wiążą się skandale dotyczące m.in. z nadużyć w Ministerstwie Finansów Republiki Czeskiej, przetargów zbrojeniowych, ustawy o grach losowych. 
tycznego w Czechach i tzw. kontekst sytuacyjny, bowiem - jak udowadnia Sebastian Przybyszewski - „,by zrozumieć wypowiedź, nie wystarcza samo przypisanie słowom sensów, trzeba jeszcze przypisać im odpowiednią referencję, a więc określić kontekst, do którego się one odnoszą" (Przybyszewski 2009, s. 179). Tak jest m.in. w przypadku przykładów Al Čapone, Lex Babiš, vinóza, kalouskovat, na klause, uklausit. Przezwiska służą do demonstrowania określonej postawy emocjonalnej wobec opisywanych osób, która na ogół wyraża krytykę i niechęć, rzadko kiedy są dowodem uznania ich autorytetu. Jedynym politykiem, który budzi w świadomości internautów zarówno negatywne, jak i pozytywne skojarzenia, jest nieżyjący prezydent Václav Havel. Podkreślić jednocześnie należy, że pogardliwie traktowani są nie tylko sami politycy, ale również ich zwolennicy (owo wartościowanie widoczne jest głównie na płaszczyźnie znaczeniowej, w mniejszym stopniu na płaszczyźnie formalnej, słowotwórczej), por. np. $b a-$ biština, klausoid, klausovka, klausovita, havlista, havlobot, havloid, havlojed, havlovka, zemáňa, zemandertalec, zemandropitekus.

Warto również spojrzeć na budowę słowotwórczą wyrazów prezentowanych w słowniku Čeština 2.0. Czy mamy tu do czynienia z kreatywnością, czy może jednak z powielaniem znanych schematów słowotwórczych? Odpowiedź nie jest jednoznaczna. Na płaszczyźnie formalnej daje się zauważyć wyraźną konwencjonalność, ale efekt końcowy bywa niekiedy dość nowatorski. Warto przyjrzeć się, jakie są sposoby i kryteria wzbogacania słownictwa czeskiego wykorzystują autorzy Češtiny 2.0. Słownictwo jest najbardziej dynamiczną częścią języka. Odzwierciedlając rzeczywistość pozajęzykową, ulega ciągłym przekształceniom, reagując $\mathrm{w}$ ten sposób na zmiany warunków społeczno-kulturowych. Romuald Cudak i Jolanta Tambor uważają, że ,aby być wygodnym narzędziem porozumiewania się, komunikowania między ludźmi, [języka - przyp. J.K.] tworzy w swoim zasobie struktury pozwalające nie tylko na wskazanie, ale i nazwanie wszystkich elementów rzeczywistości. Każdy element rzeczywistości powinien mieć bowiem swoją etykietę" (Cudak, Tambor 1995, s. 197). Uzupełnianie luk nazewniczych związanych z nowymi, zmieniający- mi się realiami, odbywać się może na kilka sposobów: poprzez zapożyczanie wyrazów z innych języków, tworzenie nowych struktur słowotwórczych, bądź nadawanie strukturom już istniejącym nowych znaczeń. Jak wskazuje Jaroslav Hubáček, „tworzenie wyrazów jest w czeszczyźnie podstawowym i bardzo częstym sposobem realizacji nowych nazw; rozumiemy przez to proces derywacji, złożenia i w sposób ograniczony - skracania nazw" (Hubáček 2005, s. 96). W badanym materiale słownikowym wykorzystywane są wszystkie wymienione wyżej sposoby, choć nie wszystkie w jednakowym stopniu.

Najczęstszym sposobem pomnażania badanego słownika jest derywacja. Można odnieść wrażenie, że ogromna większość internautów odnajduje dużą przyjemność w wymyślaniu nieraz bardzo osobliwych wyrazów. Znaczna część z nich powstała w wyniku derywacji sufiksalnej, np. adéčko 'antydepresant', ajfelka 'bardzo wysoka kobieta', bramborák 'auto marki BMW', babičárna 'knajpa, karczma', salámista 'pacyfista', ronaldit. Wiele potocyzmów jest efektem uniwerbizacji, np. Havlák (letiště Václava Havla), nakupák, (nákupní centrum), běžák ${ }^{24}$ (běžnýúčet v bance), domovka (domovní prohlídka) - w policyjnym żargonie 'przeszukanie domu, mieszkania'. W podanych przykładach najczęściej wykorzystywanymi przyrostkami są -ák, -ovka, które pełnią funkcję członów określanych.

W badanym słowniku nie brak również kontaminacji słowotwórczych. Stanisław Grabias konstatuje, że ,podaje się w zasadzie dwie przyczyny krzyżowania się wyrazów: znaczeń i podobieństwo form" (Grabias 1970, s. 118). Reguła owej bliskości znaczeniowej nie sprawdza się w przypadku niektórych analizowanych jednostek. Trudno bowiem szukać pokrewieństwa semantycznego w elementach składowych wyrazów sádlokarton (sádlo 'sadło, tłuszcz' + karton 'tektura, pudełko') 'ochronna warstwa tłuszczu u człowieka', sračkogán (srač$k a$ wulg. 'biegunka' + tobogan 'rodzaj sanek') '1. 'seria kilku porażek, kłopotów w krótkim czasie', 2. 'bardzo wulgarny człowiek' (por. pol.

${ }^{24} \mathrm{~W}$ czeskim języku potocznym běžák oznacza 'trasę, ścieżkę do biegania' < běžecká trasa. 
językjak kloaka); 3. 'kanalizacja, toaleta, odpady', czy antilopa (anti+ lopat 'pić') 'abstynent'. Wymienione przykłady potwierdzają, że „procesy kontaminacji mają w pojedynczych wyrazach charakter indywidualny i niepowtarzalny ani nie dają się ująć w uogólniające prawidła" (Klemensiewicz i in. 1965, s. 192).

Odrębną kategorię stanowią hybrydy i formacje hybrydalne. Opis tych jednostek nie jest łatwy, ponieważ ich budowa słowotwórcza jest niekiedy nad wyraz skomplikowana, a wyodrębnienie w nich części składowych niełatwe ${ }^{25}$. Zazwyczaj mianem tym określa się wyraz (zarówno złożony, jak i prosty) o mieszanym, rodzimo-obcym, składzie morfemowym. W omawianym materiale są to (np.) beachar̆ 'gracz siatkówki plażowej’ (por. beachvolejbalista/beachvolejbalistka) czy wspomniane wyżej babišmen, havloween, klausoid, klausoleum, zemandropitekus.

W kilku przypadkach mamy do czynienia z nazwami powstałymi w wyniku neosemantyzacji. Istniejące w czeszczyźnie wyrazy wykorzystywane sa w odmiennym, metaforycznym znaczeniu, np. anděl, běžák, lolita ${ }^{26}$ 'dziewczyna nadużywająca w czasie rozmowy skrótu $L O L$ ' (LOL ang. laughing out loud 'śmiać się głośno'), cédéčka 'piersi w rozmiarze miseczki C lub D' (por. cédéčka = kompaktni disky 'płyty kompaktowe, CD' - w obu przypadkach użyto tego samego formantu -éčka), cvrček 'czujnik parkowania' (cvrček 'świerszcz, cykada'). Kilka przykładów zasługuje na nieco bliższe omówienie. Rzeczownik beran to przykład neosemantyzmu, który za Albeną Rangelovą można scharakteryzować jako „domácí slovo stimulované cizím jazykem”

${ }^{25}$ Por. m.in. prace: Jerzego Obary (1986) o hybrydach i półkalkach, Olgi Martin- covej (1974) o połączeniach hybrydalnych, w których autorzy wskazują m.in. na problemy z klasyfikacją i definiowaniem tego typu jednostek leksykalnych.

${ }^{26}$ Lolita dla większości Czechów to tytuł powieści Vladimira Nabokova, od imienia głównej bohaterki utworzono rzeczownik lolitka 'bardzo młoda dziewczyna o mocno wyzywającym wygladzie' (por. Hugo 2009, s. 218). W języku czeskim częściej jako nazwa własna Lolita lub apelatywizowana, np. módni styl lolita. Por. też pol. lolitka, Lolita w tym samym znaczeniu.
(Rangelová 2005, s. 160). W powszechnym rozumieniu beran to 'samiec owcy', w badanym słowniku zaś określa 'komputerową pamięć RAM', z ang. random-access memory (w skrócie $R A M$, w języku angielskim homonimiczny rzeczownik ram oznacza 'barana' oraz 'pieczątkę, stempel'), internauci wykorzystali więc (przypadkową) zbieżność form obu anglicyzmów. Neosemantyzmami na pozór wydają się być akord, antilopa, topinka. Dopiero bliższa analiza słowotwórcza pokazuje, że na skutek kreatywnej derywacji internautów powstały homonimy: akord '(poprsí) akorát do ruky' (tu rodzaj skrótu) - por. czes. akord w muzyce, w pracy, antilopa 'abstynent' (anti- + lopat 'pić') i antilopa 'zwierzę', topinka (top w znaczeniu 'najlepszy'+ formant -inka) i topinka 'grzanka'.

Stosunkowo rzadko mamy do czynienia z apelatywizacją. Przykładem może być rzeczownik fiona, oznaczający 'brzydką kobietę, dziewczynę'. Fiona to imię jednej z głównych bohaterek popularnego cyklu pełnometrażowych filmów animowanych „Shrek”, zielonookiej ogrzycy o masywnej budowie ciała, owalnej twarzy, dużym nosie i charakterystycznych uszach w kształcie trąbek. W wyniku resemantyzacji powstała ajfelka 'bardzo wysoka kobieta' (od od Eiffelova věz - nazwa najbardziej znanego obiektu architektonicznego Paryża, w języku czeskim również 'wysoka kobieta').

Zapożyczanie wyrazów z języków obcych jest zabiegiem często wykorzystywanym w słowniku Čeština 2.0. Jest to konwencjonalny sposób poszerzania zasobu leksykalnego każdego języka, „wpływy obce w języku są nieuchronnym wynikiem niezbędnej przecież wymiany dóbr materialnych i duchowych między narodami, towarzyszą wszelkim rodzajom trwalszych kontaktów między środowiskami różnojęzycznymi” (Buttler i in. 1976, s. 42). Oczywiście, można zadać pytanie, czy wszystkie zapożyczenia są używane tam, gdzie jest to absolutnie niezbędne i czy choćby niektóre z nich nie mogłyby być zastąpione przez rodzime leksemy. Czy posługiwanie się zapożyczeniami to snobizm językowy, czy konieczność?

Przy zapożyczaniu słów z języków obcych internauci najczęściej czerpią ze wzorów angielskich, niekiedy niemieckich, sporadycznie 
z innych: japońskich ${ }^{27}$, arabskich. Zazwyczaj mamy do czynienia ze sczeszczeniem wyrazu obcego i jego adaptacją fonetyczną i słowotwórczą na gruncie czeskim, np. aglina 'brzydka dziewczyna' z ang. ugly 'brzydki' (por. czes. pot. uniwerbizowane aglina 'język angielski (jako przedmiot w szkole'), beachař/-ka 'siatkarz/siatkarka plażowa' $\mathrm{z}$ ang. beach 'plaża', čekovat 'śledzić, kontrolować' $\mathrm{z}$ ang. to check 'sprawdzić', lajtovni 'produkt oznaczony jako zawierający coś w małym stopniu' z ang. light ${ }^{28}$ 'lekki', čipák 'sknerus, skąpiec' z ang. cheap 'tani', salámista 'pacyfista; osoba bez wyraźnych poglądów' $\mathrm{z}$ arabskiego salam alejkum 'pokój z tobą'. Ciekawym przykładem wydaje się być przymiotnik babltý bardzo kolorowy, wyglądający niezdrowo', będacy sczeszczona forma angielskiego wyrażenia $b u b b$ le tea, w którym ang. tea [ti:] 'herbata' staje się czeskim przyrostkiem przymiotnikowym -tý. Niekiedy obserwujemy thumaczenie wyrazu obcego bądź jego części, np. chytrák 'smartfon' z ang. smartphone. Częstym zjawiskiem jest również uniwerbizacja, w wyniku której niejednokrotnie powstają hybrydy, np. ajták (pracovník IT), ajpina (IP adresa).

Również sufiks -ing, używany w języku angielskim m.in. do tworzenia rzeczowników odczasownikowych, w analizowanym słowniku wykorzystywany jest stosunkowo często (czasem w sczeszczonej wersji -ink), por. czes. bojing 'strach przed lataniem samolotem Boeing $737 \mathrm{Max}^{, 29}$, houbing (czes. houbařeni) 'grzybobranie', knajpink 'odwiedzanie jednej knajpy za drugą', ležink 'leniuchowanie', myšing

${ }^{27}$ Zapożyczenia z języka japońskiego są nieliczne, pojawiają się przy hasłach odnoszących się do Tomia Okamury, czeskiego polityka japońskiego pochodzenia,

${ }^{28} \mathrm{~W}$ języku polskim ang. light odnosi się do wyrobów spożywczych, adaptowany przymiotnik lajtowy według Stownika Języka Polskiego w rozumieniu potocznym oznacza 1. 'luźny, przyjemny, spokojny'; 2. 'dobry, fajny; spoko'; 3. 'łatwy' (https://sjp.pl/lajtowy).

${ }^{29} \mathrm{Tu}$ dodatkowo podobieństwo brzmieniowe, gra słów Boeing [bołing]/[boing] i bojing od czasownika bát se - bojím se, bojíš se, boji se itd. Na stronach internetowych Čeština 2.0 znajdziemy również czasownik bojit (bát se) - brak go w korpusie języka czeskiego (www.korpus.cz) i w innych czeskich słownikach. 'praca lub gra na komputerze, z użyciem tzw. myszki komputerowej zamiast klawiatury'.

W procesie adaptacji fonetyczno-graficznej dochodzi niekiedy do asymilacji pożyczki na poziomie pisowni, bez zmian na płaszczyźnie semantycznej, np. badžet (pol. budżet) z ang. budget, ofis 'biuro' $\mathrm{z}$ ang. office, piej 'sekretarka' $\mathrm{z}$ ang. $P A$ - personal asistent 'asystentka personalna'. Wszystkie wymienione przykłady zostały zapisane w miarę fonetycznie, widzimy tu niemal regularną odpowiedniość fonemów angielskich i czeskich. Na zasadzie podobieństwa formy proponuje się emil z ang. email, mail (por. pol. e-mail/mail, pot. Emil).

Podsumowując, odpowiedź na zadane w tytule pytanie wcale nie jest oczywista i prosta, a samo pytanie ma zwrócić uwagę na złożoność badanego materiału. W słowniku Čeština 2.0 znajdziemy bowiem i konwencję, i kreację, choć w nierównych proporcjach i na różnych poziomach. Derywacja, neosemantyzacja, czy hybrydyzacja to konwencjonalne sposoby tworzenia niekonwencjonalnych wyrazów (często nieprzewidywalnych pod względem znaczeniowym, przekraczających granice poprawności językowej, grzecznościowej i nierzadko na granicy tzw. użyteczności), sposoby, które znakomicie wykorzystali twórcy analizowanego słownika. Karel Oliva podkreśla, że „do jisté míry to odráží kreativitu a jazykový vtip. Z hlediska češtiny je to pozitivní. Znamená to, že lidé mají k jazyku pozitivní vztah a dokážou si dělat legrácky" (https://echo24.cz/a/wRWcY/nova-cestina-babikos-zcapit-a-dalsi-se-siri-internetem). Już Wittgenstein stwierdził, że „Granice mego języka oznaczają granice mego świata” (Wolniewicz 1970). Odnoszac te słowa do analizowanego zbioru słownikowego, należałoby stwierdzić, że granice świata twórców Čestiny 2.0 (osób zamieszczających hasła na stronie internetowej) są bardzo odległe (o ile w ogóle istnieja), a ich kreatywność wręcz nieograniczona. Zgromadzony materiał leksykalny to przewaga kreatywności nad konwencją, często kreatywności na granicy dobrego smaku i etyki słowa. Niewykluczone, że duży wpływ na takie właśnie niebanalne posługiwanie się językiem ma świadomość anonimowości w Internecie. 
Ocena zaprezentowanych w słowniku Čeština 2.0 wyrazów nie jest jednoznaczna. Aby mogły one zostać uznane za pełnoprawne jednostki języka czeskiego, muszą być przydatne, zgodne z normami słowotwórczymi, poprawne i zrozumiałe nawet dla osób, które widzą je po raz pierwszy. Powyższa analiza pokazała, że badane wyrazy nie zawsze te warunki spełniają, ponieważ jednym z kryteriów oceny innowacji jest również ,stopień jej rozpowszechnienia wśród użytkowników danego języka oraz zasięg jej występowania" (Buttler i in. 1976, s. 45). Na ile nowe słowa prezentowane w analizowanym słowniku będa trwałe i przyjmą się w języku czeskim? Na ile sa ,efemerydami”, o których szybko zapomnimy i których używać nie będziemy? Niech odpowiedzia na to pytanie beda słowa samego Martina Kavki, który zauważa:

Novotvary ani další slova nezapadnou, ale zůstávají s námi napořád jako svědkové doby, v níž jsme žili (https://www.idnes.cz/kultura/literatura/hacknuta-cestinakniha-cestina-2-0.A181121_105322_literatura_kiz).

Zapewne tylko niektórym $\mathrm{z}$ omawianych neologizmów dane będzie na dłużej zagościć w języku czeskim, tylko niektóre $\mathrm{z}$ nich zyskają szerszy zasięg społeczny, a większości na próżno będziemy szukać ich w tekstach źródłowych, korpusie tekstowym czy Internecie.

\section{Literatura}

Buttler D., Kurkowska H., Satkiewicz H., 1976, Kultura języka polskiego, Warszawa: Państwowe Wydawnictwo Naukowe.

C udak R., T a mbor J., 1995, O języku »komputerowców«, „Język Polski” 75 , z. 3, s. 197-204.

G r a b i a s S., 1970, Kontaminacje we wspótczesnym języku polskim - próba charakterystyki, ,Annales Universitatis Mariae Curie-Skłodowska. Sectio F, Nauki Filozoficzne i Humanistyczne” 25, s. 117-145.

Hubáček J., 2005, System gramatyczny języka czeskiego. Sposoby tworzenie wyrazów, [w:] Rozwój języka czeskiego po aksamitnej rewolucji, red. M. Balowski, Racibórz: PWSZ w Raciborzu, s. 96-116.

H u g o J., 2009, Slovník nespisovné češtiny, Praha: Maxdorf.

Kaproń-Charzyńska I., Wi śn iew ski M., Kreatywność leksykalna a etyka słowa, „Poznańskie Studia Polonistyczne, Seria Językoznawcza” 25 (45), nr 1, s. 77-92.
K a v k a M., Š k raba 1 M. a kol., 2018, Hacknutá čeština - neortodoxní slovník dnešni mateřštiny, Jan Melvil Publishing.

K le m e n s i e w i c z Z., 1965, Higiena językowego obcowania, „Język Polski” 65 , s. $1-8$.

K le me ns i ew ic z Z., Le hr-S pławiński T., Urbańc zyk S., 1965, Gramatyka historyczna języka polskiego, Warszawa: Państwowe Wydawnictwa Naukowe.

M a r c j a n i k M., 2007, Grzeczność w komunikacji językowej, Warszawa: Wydawnictwo Naukowe PWN.

M a r t i n c o v a O., 1974, Tzv. hybridní složeniny jako lexikální inovace, [w:] Studia z filologii polskiej i stowiańskiej, tom 13, Warszawa, s. 171-183.

M a ź n i c a Ł., 2013, Kultura, kreatywność, innowacyjność, [w:] Kultura a rozwój, seria Kultura się liczy, red. J. Hausner, A. Karwińska, J. Purchla, Narodowe Centrum Kultury, s. 399-412.

O b a r a J., 1986, Hybrydy i pótkalki na tle innych jednostek językowych obcego $i$ rodzimego pochodzenia, [w:] Formacje hybrydalne w językach stowiańskich, red. S. Warchoł, Lublin, s. 59-73.

P a s t u c h ow a M., 2008, Ukryte dziedzictwo. Ślady dawnej leksyki w stownictwie wspótczesnej polszczyzny, Katowice. Wydawnictwo Uniwersytetu Śląskiego.

Przybyszewski S., 2009, Kilka uwag o roli kontekstu w komunikacji, [w:] „Prace Językoznawcze”, z. 11, s. 179-189.

R a n g l lov á A., 2005, Neosémantizmy a neosémantizačni procesy, [w:] Neologizmy v dnešní češtině, Praha: Ústav pro jazyk česky Akademie věd České republiky, s. 159-179.

W olni ew ic z B., 1970, Wstep do Tractatus Logico-Philosophicus, Warszawa: Państwowe Wydawnictwo Naukowe.

Z a vře lová M 2018, Čvančary a milošekunda. Až sem dospěla současná čeština. Online: www.idnes.cz, 21.11. [również: https://www.idnes.cz/ kultura/literatura/hacknuta-cestina-kniha-cestina-20.A181121_105322_literatura_kiz; dostęp 15.08.2019]. 